\title{
Y-chromosomal genes affecting male fertility: A review
}

\author{
Jasdeep Kaur Dhanoa, Chandra Sekhar Mukhopadhyay and Jaspreet Singh Arora \\ School of Animal Biotechnology, Guru Angad Dev Veterinary and Animal Sciences University, Ludhiana - 141 004, \\ Punjab, India. \\ Corresponding author: Chandra Sekhar Mukhopadhyay, e-mail: csmbioinfo@gmail.com, \\ JKD: jasdeep7dhanoa@gmail.com, JSA: drarora2003@gmail.com \\ Received: 28-03-2016, Accepted: 23-06-2016, Published online: 30-07-2016
}

doi: 10.14202/vetworld.2016.783-791 How to cite this article: Dhanoa JK, Mukhopadhyay CS, Arora JS (2016) Y-chromosomal genes affecting male fertility: A review, Veterinary World, 9(7): 783-791.

\begin{abstract}
The mammalian sex-chromosomes ( $\mathrm{X}$ and $\mathrm{Y}$ ) have evolved from autosomes and are involved in sex determination and reproductive traits. The Y-chromosome is the smallest chromosome that consists of 2-3\% of the haploid genome and may contain between 70 and 200 genes. The Y-chromosome plays major role in male fertility and is suitable to study the evolutionary relics, speciation, and male infertility and/or subfertility due to its unique features such as long non-recombining region, abundance of repetitive sequences, and holandric inheritance pattern. During evolution, many holandric genes were deleted. The current review discusses the mammalian holandric genes and their functions. The commonly encountered infertility and/or subfertility problems due to point or gross mutation (deletion) of the Y-chromosomal genes have also been discussed. For example, loss or microdeletion of sex-determining region, Y-linked gene results in XY males that exhibit female characteristics, deletion of RNA binding motif, Y-encoded in azoospermic factor $b$ region results in the arrest of spermatogenesis at meiosis. The holandric genes have been covered for associating the mutations with male factor infertility.
\end{abstract}

Keywords: holandric genes, male fertility, microdeletion sex-chromosome, spermatogenesis.

\section{Introduction}

The sex-chromosomes are critical players in determining the sex of almost all of the multicellular organisms. The Y-chromosome is one of the two sex-chromosomes in mammals and is usually the smallest chromosome in the karyotype. Y-chromosome is suitable for studying the evolutionary relics, speciation, and male infertility and/or subfertility due to its unique features such as long non-recombining region and holandric inheritance pattern [1]. Nettie Maria Stevens (along with Edmund Beecher Wilson) identified that Y-chromosome is a sex-determining chromosome as early as in 1905 while conducting one study on the mealworm (Tenebrio molitor) [2]. She also proposed that chromosomes always existed in pairs. All chromosomes normally appear to assume a well-defined shape during mitosis when observed under a microscope. This shape is vaguely X-shaped for all chromosomes. Interestingly, the Y-chromosome looks like the English alphabet "Y" during mitosis due to merging of the two very short branches [3]. The $\mathrm{X}$ - and Y-chromosomes are thought to have evolved from a pair of identical chromosomes, known as autosome. The mammalian males are heterogametic (produce $\mathrm{X}$ - and Y-chromosomes bearing sperms in equal proportion), and the females are homogametic (all ova are X-bearing). It was found that Y-chromosome has

Copyright: Dhanoa, et al. Open Access. This article is distributed under the terms of the Creative Commons Attribution 4.0 International License (http://creativecommons.org/licenses/ by/4.0/), which permits unrestricted use, distribution, and reproduction in any medium, provided you give appropriate credit to the original author(s) and the source, provide a link to the Creative Commons license, and indicate if changes were made. The Creative Commons Public Domain Dedication waiver (http:// creativecommons.org/publicdomain/zero/1.0/) applies to the data made available in this article, unless otherwise stated. high repetitive DNA sequence content, which consists of pseudogenes and does not have any function [4].

\section{Structure and Organization of Y-chromosome}

Y-chromosome is the smallest chromosome that consists of $2-3 \%$ of the haploid genome and may contain between 70 and 200 genes [5]. In general, the mammalian Y-chromosome has two arms that harbor two pseudoautosomal regions (PAR1 and PAR2), which recombine with their homologous regions on $\mathrm{X}$-chromosome; and a male-specific Y region (MSY) (or non-recombining region on $\mathrm{Y}[\mathrm{NRY}]$ ), which does not recombine with the $\mathrm{X}$-chromosome. The absence of recombination makes the genetic mapping of the Y-specific region impossible, and the complexity of the repetitive sequences makes the physical mapping of the Y-specific region difficult. These PAR1 and PAR2 consist of $5 \%$ of the entire chromosome [5]. Being male-specific, the holandric genes are mostly involved in male sex determination, fertility, and development. Y-chromosome is present in different shapes and sizes in different species. In humpless cattle (Bos taurus), it is a small submetacentric, whereas in humped zebu (Bos indicus), it is a small acrocentric with visible small p-arm ("p" for "petite," means small); in river buffalo (Bubalus bubalis), it is a small acrocentric chromosome, whereas in both sheep (Ovis aries) and goat (Capra hircus), it is very small and metacentric [6,7]. The repeat sequences of Y-chromosomes have also been studied to associate with spermatological parameters [8].

\section{Important Genes Harbored by Mammalian Y-chromosomes}

In 1976, Tiepolo and Zuffardi first reported the involvement of Y-chromosome in male infertility [9]. 
It was hypothesized that during the course of evolution the Y-chromosome has acquired a large number of testes-specific genes responsible for spermatogenesis and any deletion in these genes results in infertility [10]. Mukhopadhyay reviewed that sequencing of human Y-chromosome has revealed that there are 34 genes in human PAR and 156 known transcription units in human MSY [11]. The microdeletions at Yq11 represent etiological factor with idiopathic azoospermia or oligozoospermia [11]. The SRY gene (sex determining region of $\mathrm{Y}$ ) is responsible to elicit testis determination and male development. Loss or microdeletion of SRY gene results in XY male exhibiting feminine characteristics (known as Swyer syndrome or XY gonadal dysgenesis) [12]. Some of the important genes, viz., regions (azoospermic factor [AZF]) on the mammalian Y-chromosome have been discovered and later characterized. These genes have been covered in this review. Important features such as cytogenetic location, function, and mutational deficiencies associated with some of the holandric genes are adumbrated in the Table-1.

\section{Functions of Genes on Y-chromosome}

AZF

AZF, distributed through three genetic regions (namely, AZFa, AZFb, and AZFc), is name of a region (not a single gene) on the long arm of human Y-chromosome (Yq11.2: "q" for queue means tail) that shelters a number of protein coding genes associated with spermatogenesis [5]. The AZFa harbors some single copy genes (involved in spermatogenesis) that have X-homologs. The overlapping AZFb and $A Z F c$ regions are jointly termed as AZF2. In $\mathrm{AZFb}$ region, the eukaryotic translation initiation factor 1A, Y-linked (EIFIAY) and RNA binding motif, and Y-encoded (RBMY) genes have been mapped in man [13]. EIF1A protein is involved in stabilizing the binding of the initiator methionine-bearing-tRNA to $40 \mathrm{~S}$ ribosomal subunits. The AZFc region harbors five genes: Deleted in azoospermia $(D A Z)$, chromodomain Y1, basic protein Y2 (BPY2), PTA-BL related $\mathrm{Y}(P R Y)$, and testis transcript $\mathrm{Y} 2$ [14].

\section{Ubiquitin-specific peptidase 9, Y-linked (USP9Y)}

USP9Y (initially known as Drosophila fat facets related $\mathrm{Y}$ ) is a single copy gene, located in the AZFa region. USP9Y enzyme belongs to the peptidase $\mathrm{C} 19$ family and has role in sperm cell development in mammals. USP9Y enzyme is similar to the ubiquitin-specific proteases, which cleave the ubiquitin moiety from ubiquitin-fused precursors and ubiquitinated proteins [14].

\section{BPY2}

This male-specific gene encodes testis-specific BPY2 in mammals, which interacts with ubiquitin protein ligase E3A, which are enzymes that target other proteins to be broken down (degraded) within cells. These enzymes attach a small protein called ubiquitin to proteins that should be degraded. The gene is located in two copies within a palindromic region at Hsa-Yq11 in man.

\section{Protein kinase, Y-linked pseudogene (PRKY)}

PRKY is a serine/threonine-protein kinase enzyme that is encoded by the $P R K Y$ "transcribed pseudogene which is located on Y-chromosome near the PAR in human." Hamamah et al. [15] isolated and characterized the $P R K Y$ gene in man, which is highly homologous to the $P R K X$ gene on $\mathrm{Xp} 22.3$. Sex reversal in human $\mathrm{XX}$ male and $\mathrm{XY}$ females results due to sex-chromosomal translocation $(\mathrm{X} ; \mathrm{Y})$ (p22;p11) between proximal part of PRKY and its X-homologue PRKX [15].

\section{RBMY}

RBMY encodes a germ cell-specific nuclear protein involved in spermatogenesis. It is a multicopy gene family with 30-40 members (nested in the $\mathrm{AZFb}$ region), most of which are pseudogenes. The encoded protein contains an RNA-binding motif in the N-terminus and four serine, arginine, glycine, and tyrosine (SRGY) boxes in the C-terminus. In men, six highly similar copies (RBMY1 to 6) have full-length ORFs and are considered functional [16]. RBMY shares high homology with an autosomal heterogeneous nuclear ribonucleoprotein $\mathrm{G}(h n R N P-G)$ gene that contains an RNA-binding motif and one of the four SRGY repeats found in RBMY, suggesting that RBMY functions as an RNA processing factor. The $h n R N P-\mathrm{G}$ is a nuclear protein whose function is unknown that binds nascent pre-mRNA in vivo and in nuclear extracts. RBMY1 siRNA(h) is recommended for the inhibition of RBMY1 expression in human cells [16]. RBMX is homologous of $R B M Y$ present on human Xp26. In mice, $R B M Y$ is not expressed in intermediate spermatocytes, but it is expressed discontinuously in the spermatogonia and elongated spermatids. RBMY gene is present in Y-chromosome of higher primates and is absent in other eutherian and marsupial species. Human and mouse $R B M Y$ have an $\mathrm{X}$-chromosomal paralogue $(R B M X)$, which encodes the widely expressed hnRNP-G [17].

\section{DAZ}

The DAZ gene family, with three functional copies, viz., DAZ-1, -2, and -3, is expressed only in the mammalian male germ cells. Reports suggest that $D A Z$ and DAZ-like 1 (DAZLI) genes control the cell cycle switch from mitotic to meiotic cell division through the RNA recognition motifs on these gene products [18]. The presence of a wide array of DAZ transcripts in single individual suggests that the transcripts could also have arisen by alternative splicing of a single gene. Four copies of this gene are found within the palindromic duplications on human Y-chromosome: One pair of genes as a part of the P1 palindrome and the second pair as a part of the P2 palindrome. Each gene consists of $2.4 \mathrm{~kb}$ repeat (that encodes 24 amino acids) with 72 bp exon [19]. The $D A Z L 1$ is an autosomal gene present in all vertebrates 
Table-1: Cytogenetic location, major functions, salient features, and disorders associated with aberrations associated with mammalian Y-chromosome.

\begin{tabular}{|c|c|c|c|}
\hline $\begin{array}{l}\text { Gene name, size, } \\
\text { location* }\end{array}$ & Expression & Role/Function & Disorder \\
\hline $\begin{array}{l}\text { USP9Y, } 2555 \mathrm{aa}, \\
\text { Yq11.2 }\end{array}$ & $\begin{array}{l}\text { Embryonic and adult } \\
\text { tissues including } \\
\text { testis }\end{array}$ & Spermatogenesis & $\begin{array}{l}\text { Sertoli cell only syndrome, } \\
\text { Y-chromosome based } \\
\text { infertility, impaired or no } \\
\text { sperm production [69] }\end{array}$ \\
\hline $\begin{array}{l}\text { BPY2, } 106 \text { aa, } \\
\text { Yq11.223 }\end{array}$ & Testis & $\begin{array}{l}\text { Male germ cell development, } \\
\text { male infertility }\end{array}$ & $\begin{array}{l}\text { Y-chromosome infertility, } \\
\text { male infertility, spermatogenic } \\
\text { failure, Y-linked } 2[70]\end{array}$ \\
\hline RBMY, 391 aa & Developing germ cells & $\begin{array}{l}\text { Transcriptional regulation } \\
\text { processes, tumor } \\
\text { suppression }\end{array}$ & $\begin{array}{l}\text { Infertility in males [17], } \\
\text { deletion in mice results } \\
\text { in high level of sperm } \\
\text { development }[16]\end{array}$ \\
\hline $\begin{array}{l}\text { DAZ, } 744 \text { aa, } \\
\text { Yq11.223 }\end{array}$ & $\begin{array}{l}\text { Restricted to } \\
\text { pre-meiotic germ } \\
\text { cells, particularly in } \\
\text { spermatogonia }\end{array}$ & $\begin{array}{l}\text { Spermatogenesis, } \\
\text { translational regulation, } \\
\text { promotes germ-cell } \\
\text { progression to meiosis and } \\
\text { formation of haploid germ } \\
\text { cells }\end{array}$ & $\begin{array}{l}\text { Persistent fetal circulation } \\
\text { syndrome, azoospermia, } \\
\text { deletion of DAZL1 in mouse } \\
\text { results in complete absence } \\
\text { of gamete production and } \\
\text { reduced number of germ } \\
\text { cells [18] }\end{array}$ \\
\hline SRY, 204 aa, Yp11.3 & $\begin{array}{l}\text { Adult testis by germ } \\
\text { cells }\end{array}$ & $\begin{array}{l}\text { Sex determination acts as } \\
\text { transcriptional regulator, } \\
\text { promotes DNA bending, } \\
\text { involved in pre-mRNA } \\
\text { splicing }\end{array}$ & $\begin{array}{l}\text { Mixed gonadal dysgenesis, } \\
46 X Y \text { sex reversal } 1, \text { XX male } \\
\text { syndrome }[21]\end{array}$ \\
\hline TSPY, 308 aa, Yp11.2 & $\begin{array}{l}\text { Testis, tumor } \\
\text { germ cells of } \\
\text { gonadoblastoma } \\
\text { specimens }\end{array}$ & $\begin{array}{l}\text { Sperm differentiation } \\
\text { and proliferation, } \\
\text { cell cycle regulation, } \\
\text { transcription regulation, } \\
\text { neurotransmission, meiotic } \\
\text { division, tumor suppression } \\
\text { and promotion }\end{array}$ & $\begin{array}{l}\text { Gonadoblastoma, sudden } \\
\text { infant death with dysgenesis of } \\
\text { the testis syndrome, infertility, } \\
\text { cancers, diabetes, and neural } \\
\text { dysfunctions [71] }\end{array}$ \\
\hline $\begin{array}{l}\text { AmelogeninAMELY-206 } \\
\text { aa, Yp11.2 [29] }\end{array}$ & $\begin{array}{l}\text { Testis, ovary, lungs, } \\
\text { liver } \\
\text { (based on microarray) }\end{array}$ & $\begin{array}{l}\text { Organizing of enamel rods } \\
\text { during tooth development, } \\
\text { biomineralization }\end{array}$ & $\begin{array}{l}\text { Dental pulp necrosis, } \\
\text { dental fluorosis, } \\
\text { amelogenesisimperfecta [29], } \\
\text { deleted amelogenin males [31] }\end{array}$ \\
\hline ZFY, 801aa, Yp11.3 & Testis & $\begin{array}{l}\text { Transcriptional activator, } \\
\text { sperm or testis maturation }\end{array}$ & $\begin{array}{l}\text { Cystadenofibroma, campomelic } \\
\text { dysplasia [32] }\end{array}$ \\
\hline $\begin{array}{l}\text { DDX3Y, } 660 \text { aa, } \\
\text { Yq11.2 }\end{array}$ & $\begin{array}{l}\text { Testis, placenta, } \\
\text { ovary, uterus, lung, } \\
\text { liver, kidney } \\
\text { (based on microarray) }\end{array}$ & $\begin{array}{l}\text { Translation initiation, } \\
\text { nuclear and mitochondrial } \\
\text { splicing, embryogenesis }\end{array}$ & $\begin{array}{l}\text { Spermatogenesis, male } \\
\text { infertility, sertoli cell } \\
\text { only syndrome, severe } \\
\text { hypospermatogenesis [36] }\end{array}$ \\
\hline HSFY, 401 aa, Yq11.22 & $\begin{array}{l}\text { Testis, sertoli cell, } \\
\text { spermatogenic cells }\end{array}$ & Transcriptional activators & $\begin{array}{l}\text { Male infertility, azoospermia, } \\
\text { sertoli cell only syndrome, } \\
\text { oligospermia [72] }\end{array}$ \\
\hline $\begin{array}{l}\text { KDM5D, } 1539 \text { aa, } \\
\text { Yq11 }\end{array}$ & $\begin{array}{l}\text { Testis, ovary, whole } \\
\text { blood, kidney } \\
\text { (based on microarray) }\end{array}$ & Histone coding & Y-chromosome infertility [14] \\
\hline $\begin{array}{l}\text { RPS4Y2, } 263 \mathrm{aa}, \\
\text { Yq11.22 }\end{array}$ & $\begin{array}{l}\text { Testis, prostate, } \\
\text { whole blood } \\
\text { (based on RNAseq) }\end{array}$ & Spermatogenesis & Y-chromosome infertility [39] \\
\hline PRY, 147 aa, Yq11.22 & Testis & $\begin{array}{l}\text { Spermatogenesis, apoptosis } \\
\text { of defective spermatozoa }\end{array}$ & $\begin{array}{l}\text { Y-chromosome infertility, } \\
\text { azoospermia }\end{array}$ \\
\hline CDY, 598 aa, Yq11.23 & Testis & $\begin{array}{l}\text { Chromatin targeting and } \\
\text { maximal enzymatic activity } \\
\text { of PRC2, acts as a positive } \\
\text { regulator of PRC2 activity }\end{array}$ & Gingival recession \\
\hline $\begin{array}{l}\text { AKAP17A, } 695 \text { aa, } \\
\text { Yp11.32 }\end{array}$ & $\begin{array}{l}\text { Testis, prostate, ovary } \\
\text { (based on microarray } \\
\text { and RNAseq) }\end{array}$ & $\begin{array}{l}\text { Regulation of pre-mRNA } \\
\text { splicing }\end{array}$ & Chronic tic disorder \\
\hline CD99, 185 aa, Yp11.3 & $\begin{array}{l}\text { Testis, prostate, } \\
\text { ovary (based on } \\
\text { microarray and } \\
\text { RNAseq) }\end{array}$ & $\begin{array}{l}\text { T-cell adhesion and } \\
\text { spontaneous rosette } \\
\text { formation with erythrocytes, } \\
\text { helping leukocytes to } \\
\text { overcome the endothelial } \\
\text { basement membrane }\end{array}$ & $\begin{array}{l}\text { Testicular fibroma, testicular } \\
\text { granulosa cell tumor }\end{array}$ \\
\hline $\begin{array}{l}\text { TGIF2LY, } 185 \text { aa, } \\
\text { Yp11.2 }\end{array}$ & $\begin{array}{l}\text { Testis (based on } \\
\text { RNAseq) }\end{array}$ & $\begin{array}{l}\text { Transcription role in testis, } \\
\text { act as a competitor/ } \\
\text { regulator of TGIF2LX }\end{array}$ & Prostate cancer [49] \\
\hline
\end{tabular}


Table-1: Continued...

\begin{tabular}{llll}
\hline $\begin{array}{l}\text { Gene name, size, } \\
\text { location* }\end{array}$ & Expression & Role/Function & Disorder \\
\hline TBL1Y, 522 aa, Yp11.2 & $\begin{array}{l}\text { Testis, prostate, } \\
\text { ovary (based on } \\
\text { microarray and } \\
\text { RNAseq) }\end{array}$ & Transcription activator & Deafness sensorineural [73] \\
VCY, 125 aa, Yq11.22 & $\begin{array}{l}\text { Testis, male germ } \\
\text { cells }\end{array}$ & $\begin{array}{l}\text { Spermatogenesis } \\
\text { Sex ratio distortion }\end{array}$ & $\begin{array}{l}\text { Y-chromosome infertility, } \\
\text { X-linked ichthyosis, } \\
\text { gonadoblastoma [53] } \\
\text { NLGN4Y, 816 aa, }\end{array}$ \\
Yq11.22 & $\begin{array}{l}\text { Testis, prostate, } \\
\text { ovary (based on } \\
\text { microarray and } \\
\text { RNAseq) }\end{array}$ & Cell-cell interactions & tuberculosis, autistic \\
& disorder [54]
\end{tabular}

*Cytogenetic location in human. PRC2=Polycomb repressive complex 2

while $D A Z$ is found in old world monkeys. The cynDAZL1, isolated from the crab-eating cynomolgus monkey, contains one $D A Z$ repeat and displays high homology to humans $D A Z L 1$. The immunolocalization studies of cynDAZL1/DAZL1 in cynomolgus monkey testis revealed a biphasic expression pattern with proteins being detectable in a range of developing sperm cells, viz., spermatogonia and late spermatocytes, however, not in early spermatocytes and late spermatids [18].

\section{SRY}

$S R Y$, are gulator of testis-determining factor (TDF), is an intronless, sex-determining gene that islocated on the short arm of Y-chromosome in man [20]. The most convincing evidence on the role of SRY on testis formation was obtained from the experiment of Wilhelm et al. [21], where they microinjected 14-kb region of DNA including the $S R Y$ gene (and its regulatory elements) into the genome of a normal XX mouse zygote [21]. The XX embryos were reported to develop testes, male accessory organs, and penis. The SRY-locus was the first identified as a member of the SOX transcription factor family [22]. SOX9 is an autosomal gene which is involved in sex determination. It encodes a transcriptional factor that contains high mobility group (HMG) box. $S R Y$ comprises of a conserved DNA binding domain (HMG-box) of a single exon, encoding 204 amino acid proteins which regulate gene expression. In fetal mice, $S R Y$ is expressed in somatic cells of genital ridge, while in sheep expression persists even after full differentiation of testis and in human and marsupials, $S R Y$ transcripts can also be detected in other fetal and adult tissues [23].

\section{Testes-specific protein, Y-encoded (TSPY)}

This is a multicopy gene (between 20 and 40 among individuals), present in the NRY. This $33-\mathrm{kDa}$ protein encoded by this gene is found only in testicular tissue and may be involved in spermatogenesis. The immune-histochemical data of TSPY expression suggested that it is responsible for the proliferation of germ cells [24]. Testes being the primary site of expression, the TSPY are expressed in spermatogonia, to lesser degree primary spermatocytes and in prostate-cancer tissue and cells. However, only a single, non-functional orthologous gene is found in mice. In human, two transcript variants encoding different isoforms have been found for this gene [25]. Gene isoforms are mRNAs that are produced from the same locus but are different in their transcription start sites. The gene is predominantly expressed in adult testes and to some extent in fetal testes due to the lower content of germ cell precursor stages [25]. TSPY is a good male-specific marker so can be used for sex determination in animals [26]. TSPY has been studied to identify SNPs associated with spermatological quality in cattle and buffalo [27, 28].

\section{Amelogenin}

This extracellular matrix protein is involved in amelogenesis (i.e., development of enamel) of tooth. Each of the sex-chromosomes harbor one amelogenin gene. Sasaki and Shimokawa [29] first isolated and sequenced human amelogenin gene. This gene is present on both the sex-chromosomes in anthropoids (gorilla, chimpanzee, and orangutan) and bovines, some old world monkey (Japanese monkey, rhesus monkey, crab-eating macaque) but present on only $\mathrm{X}$-chromosome in other old world monkey (baboon, patas monkey, and green monkey) [30]. Amelogenin gene is present in two forms, viz., AmelX and AmelY, which differ by a 6 bp deletion in AmelX. Polymerase chain reaction (PCR)-gel electrophoresis reveals two bands of DNA in males at 106 and $112 \mathrm{bp}$, and a single band at $106 \mathrm{bp}$ in human females. It makes amelogenin a candidate of sex determination [31].

\section{Zinc finger gene, Y-chromosome (ZFY)}

$Z F Y$ gene was originally an autosomal and was relocated to the $\mathrm{X}$ - and $\mathrm{Y}$-chromosomes in eutherians along with neighboring genes, but it does not pass the marsupial test which indicates that it is not the ancestral TDF. In mice testicles, 2 zfy genes (zfyl and $z f y 2)$ are expressed while in human there is no report of function of zfy in testis [32]. The expression of these genes increases in germ cells entering meiosis. $Z F X$ is the homologue of $Z F Y$ that encodes similar proteins and it is the regulator of self-renewal of hematopoietic 
stem cells and embryonic cells. Cloning and comparative analysis of $Z F X$ and $Z F Y$ genes have been recently reported for bovine, porcine, and equine homologs. A high degree of similarity of bovine $Z F X$ and $Z F Y$ genes was found to each other and with other species [33]. The $Z F Y$ gene is located on the R-bandpositive region of Y-chromosome in cattle (exotic and zebu) and riverine buffalo [6].

Ubiquitously transcribed tetratricopeptide repeat containing, Y-encoded (UTY)

In human, thesix mRNA transcripts of UTY gene translate into the enzyme histone demethylase UTY that contains tetra-trico-peptide repeats and are thought to be involved in protein-protein interactions. The UTY protein being a minor histocompatibility antigen could induce rejection of male stem cell grafts. Suppression of recombination between the homologous genes UTY and X-chromosomal UTX, results in a point mutation in mRNA transcripts of these genes, whereas the reading frames, viz., the protein domain structures are conserved [34]. UTYderived peptides elicit immune-recognition in human and the mouse [35]. UTY plays major role in translational research on immunotherapy of leukemia, which prevent tumor relapse in post-transplant patients. In a male-recipient/female-donor setting, $U T Y$-specific peptides exhibit a gender-specific antitumor effect, observed mainly in vitro [34].

DEAD (Asp-Glu-Ala-Asp) box helicase 3, Y-linked or DEAD box protein 3, Y-linked (DDX3Y)

$D D X 3 Y$ gene, also known as $D B Y$ gene, encodes a DEAD box protein which is characterized by the conserved motif Asp-Glu-Ala-Asp and is basically an enzyme [36]. It was reported that in mice treated with arsenic the expression of $D D X 3 Y$ was down-regulated in testis and epididymis. This gene also has a homolog on X-chromosome $(D D X 3 X)$ [36].

\section{Heat shock transcription factor, Y-linked (HSFY1 and HSFY2)}

HSFY belongs to HSF family and is involved in the spermatogenesis in animals as well as humans. $H S F Y 2$, a protein coding gene, is a candidate gene for azoospermia. This gene is present in two identical copies in genome with palindromic region. Realtime (RT)-PCR showed that $H S F Y$ family is largely expanded in cattle ( $\otimes 70$ copies) as compared to human (2 functional copies, 4 HSFY-similar copies). $H S F Y$ expression in cattle appears to be restricted to the testis. The mRNA levels of $H S F Y$ varied significantly between bulls $(p<0.0001)$ and correlates positively with mRNA markers of spermatogonial and spermatocytes [37].

Lysine (K)-specific demethylase 5D (KDM5D) and ribosomal protein S4, Y-linked 2 (RPS4Y2)

KDM5D and RPS4Y2 both are protein coding encodes genes.KDM5D gene (also known as HY, HYA, SMCY, and JARID1D) encodes a protein containing zinc finger domains. A short peptide derived from this protein is a minor histocompatibility antigen which can lead to graft rejection of male donor cells in a female recipient. Alternative splicing results in multiple transcript variants [38]. RPS4Y2 is a protein of 40 s ribosomal subunit, which is encoded by testis-specific RPS4Y2 gene in human [39].

\section{PTPN13-like, Y-linked (PRY)}

$P R Y$, a testis-specific protein-coding gene, was first reported by Lahn and Page [40]. This gene has four functional copies (PRY1-PRY4). The first two copies located in $\mathrm{AZFb}$ and encode a protein tyrosine phosphate that play role in spermatogenesis. PRY3 and PRY4 are located in AZFc region, and consist of 3,4 , or 5 exons. Yu et al. suggested that $P R Y$ has no significant role in spermatogenesis, but it is involved in apoptosis of mature sperm [41].

\section{Chromodomain protein Y-linked (CDY)}

This gene consists of three members: One member located on Y-chromosome and two on autosomes (CDYL and CDYL2), which have been identified in human [42]. Two members $C D Y L$ and CDYL2 mapped to human chromosome 6 and 16 and exist in most mammalian species [43]. The bCDLY and bCDLY2 genes harbor 9 and 7 exons, respectively, and these have been mapped to bovine chromosome 24 and 18 , respectively.

\section{Protein A kinase or anchor protein 1 (PKA or XE7)}

This pseudoautosomal gene in human is ubiquitously expressed. The structure and expression of this gene was identified in human tissues [44]. Alternative RNA splicing of XE7 results in two protein isoforms of 385 and 695 amino acids. The arginine/serine $(\mathrm{R} / \mathrm{S})$-rich region in the larger of these suggests a role in mRNA processing [45]. With interaction of family of protein kinase A (PKA) anchoring proteins (AKAPs), PKA is targeted to distinct subcellular loci. Most AKAPs bind PKA through an amphipathic helix which consists of 14-18 amino acids that insert into a hydrophobic groove formed by the R-dimer as evident from resolution of nuclear magnetic resonance and crystal structures of the complex [46].

\section{MIC2 gene for CD99 molecule}

$M I C 2$ is another pseudoautosomal gene in man, which encodes a human cell surface molecule 12E7. MIC2 is a T-cell surface protein which is involved in aggregation of lymphocytes. Alternative splicing exhibits differential expression between the two forms, with the major form inducing cellular adhesion and the truncated form antagonizing this process (Santacruz Biotechnology, Inc.) [47]. Birch et al. reported the identification and characterization of MIC genes in human that were related to MHC Class I. They identified three $M I C$ genes in the genome of cattle and located them close to three non-classical $M H C$ Class I genes. Analyses of bovine cell line-specific MIC cDNA sequences indicate that in total, there may be four $M I C$ genes [48]. 
Transforming growth factor beta-induced factor homeobox 2-like, Y-linked (TGIF2LY)

This gene lies within the MSY region, in a block of sequence that is thought to be the result of a large $\mathrm{X}$-to-Y transposition. The $\mathrm{C}$-terminus of this protein is divergent from that of its $\mathrm{X}$-chromosome homolog (TGIF2LX), suggesting that this protein may act as a regulator of TGIF2LX. This gene encodes a member of the TALE/TGIF homeobox family of transcription factors. Any change in TGF2LY gene results in azoospermia and infertility) [49]. TGIFLX/Y is homeodomain-containing genes with 2666-bp mRNA being encoded by two exons separated by a $96-b p$ intron. Comparative DNA analysis indicates that TGIFLX originated from retrotransposition of TGIF2, located on 20q11.2-12, onto the X-chromosome. RT-PCR analysis has revealed that $\mathrm{X}$ - and $\mathrm{Y}$-linked genes were expressed in the adult testis [50].

\section{Transducin beta-like 1, Y-linked (TBL1Y)}

The TBL1Y protein has sequence similarity with members of the WD40 repeat-containing protein family. Ramadoss et al. reported that TBL1 controls the expression of nuclear factor- $\mathrm{\kappa B}(\mathrm{NF}-\mathrm{\kappa B})$ target gene (which controls tumor progression) by directly binding with NF- $\kappa B$ facilitating its recruitment to target gene promoters. TBL1 knockdown significantly reduced the invasive potential of breast cancer cells by inhibiting $\mathrm{NF}-\kappa \mathrm{B}$ [51]. TBL1Y is also involved in the genesis of non-syndromic coarctation of the aorta [52].

\section{Variable charge, Y-linked 1 (VCY1) and VCY2}

These are variable charged proteins located in deleted AZFc region in infertile men. Members of the VCX/Y family share a high degree of sequence identity, with the exception that a 30-bp unit is tandemly repeated in X-linked members but occurs only once in Y-linked members [53]. $V C Y 2$ is testis-specific gene and located in most frequently deleted $\mathrm{AZFc}$ region of Y-chromosome. $V C Y 2$ is composed of 8 exons, of which, 5 are translated to amino acids. Cao et al. reported that due to the impaired expression of $V C Y 2$ in infertile men, this gene is involved in the pathogenesis of male infertility [53].

\section{Neuroligin 4, Y-linked (NLGN1)}

This gene encodes a Type I membrane protein that belongs to the family of neuroligins, which are cell adhesion molecules present at thepost-synaptic side of the synapse, and may be essential for the formation of functional synapses. An important paralog of this gene is NLGN1. Putative neuronal cell surface protein of this gene is involved in cell-cell interactions [54].

\section{Genetic Disorders Related to Y-chromosomal Anomalies}

\section{Azoospermia}

The reproductive disorder of male known as azoospermia is characterized by absence of sperm in ejaculate affecting $\sim 20 \%$ of male fertility situations [55]. It can be classified as pre-testicular, testicular, post-testicular, and idiopathic azoospermia. A number of causes responsible for azoospermia includes: Primary or secondary testicular failure, Klinefelter syndrome [56], Y-chromosome microdeletions, genetic infertility due to abnormal chromosomes (karyotype) [41], Kallmann syndrome, hypothalamic/pituitary tumor, hyperprolactinemia, cancer treatment (chemotherapy, radiation, surgery), varicocele effect [57], pituitary suppression, diabetes mellitus, sickle cell anemia, hemochromatosis, sperm autoimmunity, undescended testicles at birth, obstruction, congenital absence of the vas deferens, ejaculatory duct obstruction, Young syndrome, and vasectomy [58]. Disease-like varicocele is associated with AZF1 (or AZFa) region of Y-chromosome [14]. EIF1A protein results in azoospermia when deleted. O'Brien et al. indicated that deletion of DAZ1/DAZ2 (however, not deletion of DAZ3/DAZ4) is associated with spermatogenic impairment [59]. The RBMYdeleted mice are fertile with normal sperm output [16]. However, RBMY knocked out mice exhibit normal spermatogenesis but develop structurally defective spermatozoa [17]. On the contrary, in human, deletion of $R B M$ results in meiotic arrest and azoospermia. The diagnosis can be performed using karyotyping, PCR, or fluorescent insitu hybridization [60].

\section{Jacobs syndrome}

It is a chromosomal genetic syndrome where the male person has an extra Y-chromosome, becoming XYY instead of normal XY (male) or XX (female). Immaturity, learning difficulties, arthritis, camptodactyly, swollen joints, and tall stature are the problems associated with Jacob's syndrome [61].

\section{Klinefeltersyndrome (47,XXY karyotype)}

This is an abnormality of sex-chromosome affecting 1 of 600 newborn males [62]. In this condition, an extra X-chromosome results in defective postnatal testicular function. This syndrome occurs due to non-disjunction of homologous chromosomes. During gametogenesis due to non-disjunctional event an extra chromosome has been retained by the gamete. Fertilization of a normal (X) egg with abnormal sperm having XY-chromosome produces an XXY offspring (Klinefelter) [63]. Hypogonadism has been suspected as a contributor to increase in morbidity and mortality due to Klinefelter syndrome [64]. This disorder is characterized by a $47, \mathrm{XXY}$ or a mosaic karyotype, hypergonadotropic hypogonadism, infertility, reduced body hair and gynecomastia. The diagnosis can be performed by hormone testing or chromosomal analysis.

\section{Male infertility}

Deletion of genetic material in the region of Y-chromosome (AZF) results in male infertility [65]. O'Brien et al. reported that the natural transmission of deletions which involves the USP9Y gene suggests that the absence of the USP9Y gene product does not preclude sperm-fertilizing ability, and thus, it is not critical for spermiogenesis [59]. This gene is present but 
inactive in chimpanzees and bonobos, however, it is absent (deleted) in infertile men [65]. Deletion in two of four holandric $D A Z$ gene copies, which is difficult to detect due to multicopy nature, will result in spermatogenic failure [59]. HSFY gene has been mapped to the $\mathrm{AZFb}$ region of human Y-chromosome whose deletion results in male infertility [37]. Any change in TGF2LY gene results in azoospermia and infertility [66]. In Europe and the Western Pacific region, it is reported that partial $\mathrm{gr} / \mathrm{gr}$ deletion of AZFc is associated withmale infertility among Caucasians [66]. Suganya et al. reported that male infertility may be caused by genetic abnormalities, varicocele, cryptorchidism, spermatic duct obstruction, urogenital tract infections, antisperm antibodies, endocrine disturbances, testicular malignancy, and environmental factors [67].

\section{Y-chromosome microdeletion}

Missing genes in Y-chromosome result in microdeletions. Y-chromosome microdeletion is currently diagnosed by extracting DNA from leukocytes and mixing it with some of the about 300 known genetic markers for sequence-tagged sites on the Y-chromosome, and then using PCR amplification and gel electrophoresis to test whether the DNA sequence corresponding to the selected markers is present in the DNA [68].

\section{Conclusion}

The advent of next generation sequencing and development of high end, faster bioinformatics tools and pipelines have enabled researchers to identify and annotate a number of novel genes. Until 1990s, the scientists speculated that the Y-chromosome is a barren land and it contains only SRY gene. However, at present at least a few dozens of Y-chromosomal genes have been studied. The Y-chromosomal genes have been explored associated with several male fertility-specific traits both in human and animals. In near future, some more new genes are expected to be explored and characterized using the most advanced sequencing technique, transcriptomics, proteomics, etc.

\section{Authors' Contributions}

All authors participated in the discussion, draf and revision of the manuscript. All authors read and approved the final manuscript.

\section{Competing Interests}

The authors declare that they have no competing interests.

\section{Acknowledgement}

The authors thankfully acknowledge the funding provided by the RKVY project "Genetic Profiling of Sahiwal and HF Crossbred Cattle for genes impacting stress tolerance and climate change."

\section{References}

1. Mukhopadhyay, C.S., Gupta, A.K., Yadav, B.R., Khate, K., Raina, V.S., Mohanty, T.K. and Dubey, P.P. (2010) Subfertility in males: An important cause of bull disposal in bovines. Asian Aust. J. Anim. Sci., 23: 450-455.

2. Morgan, T.H. (1912) The scientific work of miss N. M. Stevens. Science, 36: 468-470.

3. Bainbridge, D. (2003) The X in Sex: How the X Chromosome Controls Our Lives. Vol. 13. Harvard University Press, Cambridge, MA. p3-5.

4. Haseltine, P.F., Michael, E., McClure, M.E. and Goldberg, E.H. (2013) Genetic markers of sex differentiation. Psychology, 3: 107.

5. Bichile, D.L., Kharkar, A.R., Menon, P., Potnis-Lele, M., Bankar, M. and Shroff, G.A. (2014) Y chromosome: Structure and biological functions. Indian J.Basic Appl. Med. Res., 3: 152-160.

6. Cabelova, K., Kubickova, S., Cernohorska, H. and Rubes, J. (2012) Male-specific repeats in wild Bovidae. J. Appl. Genet., 53: 423-433.

7. Jamir, J., Mukhopadyay, C.S., Arora, J.S., Brah, G.S., Cheema, R. and Kaur, M. (2015) Screening of dairy breeding bulls for chromosomal profile and its andrological attributes. Indian J. Anim. Res., 49: 8-13.

8. Kaur, M., Kaur, A., Jamir, J., Arora, J.S., Brah, G.S., Cheema, R., Kaur, S. and Mukhopadhyay, C.S. (2012a) Y-Chromosomal STR Loci Vis-À-Vis Andrological Parameters in Dairy Bulls, Paper Presented in the $\mathrm{XI}^{\text {th }}$ Annual Convention of IAVPHS and International Symposium on "One Health: Way Forward to Challenges in Food Safety and Zoonosis in $21^{\text {st }}$ Century.

9. Suganthi, R., Vijesh, V.V., Vandana, N. and Ali Benazir, J.F. (2014) Y Choromosomal microdeletion screening in the workup of male infertility and its current status in India. Int. J. Fertil. Steril., 7: 253-266.

10. Kucukaslan, A.S., Cetintas, V.B., Altıntas, R., Vardarli, A.T., Mutlu, Z., Ulukus, M., Semerci, B. and Eroglu, Z. (2013) Identification of $\mathrm{Y}$ chromosome microdeletions in infertile Turkish men. Turk. J. Urol., 39(3): 170-174.

11. Mukhopadhyay, C.S. (2013) Genomic DNA Markers for Male Fertility. Presented in ICAR Sponsored "Updates on Male Infertility, Semen Technology and Quality Oocyte Production". Delivered on $25^{\text {th }}$ September' 2013 at Department of Gynecology and Obstetrics, GADVASU, Ludhiana, Organized during $16^{\text {th }}$ September to $7^{\text {th }}$ October'. 2013.

12. Wisniewski, A.B. (2012) Gender development in 46, XY DSD: Influences of chromosomes, hormones, and interactions with parents and healthcare professionals. Scientifica, 2012: 15

13. Kleiman, S.E., Yogev, L., Hauser, R., Botchan, A., Maymon, B.B.S., Paz, G. and Yavetz, H. (2007) Expression profile of AZF genes in testicular biopsies of azoospermicmen. Hum. Reprod., 22: 151-158.

14. Navarro-Costa, P., Plancha, C.E. and Goncalves, J. (2010) Genetic dissection of the AZF regions of the human Y chromosome: Thriller or filler for male (In)fertility. J. Biomed. Biotechnol., 2010: 18.

15. Hamamah, S., Mieusset, R. and Olivennes, F. (2012) Medical. Male Sterility and Motility Disorders: Etiological Factors and Treatment.Springer-Verlag, New York.

16. Skrisovska, L., Bourgeois, C.F., Stefl, R., Grellscheid, S.N., Kister, L., Wenter, P., Elliott, D.J., Stevenin, J. and Allain, F.H.T. (2007) The testis-specific human protein RBMY recognizes RNA through a novel mode of interaction. EMBO Rep., 8: 372-379.

17. Abid, S., Sagare-Patil, V., Gokral, J. and Modi, D. (2013) Cellular ontogeny of RBMY during human spermatogenesis and its role in sperm motility. J. Biosci., 38: 85-92.

18. Yu, Y.H., Lin, Y.W., Yu, J.F., Schempp, W. and Yen, P.H. (2008) Evolution of the DAZ gene and the AZFc region on primate Y chromosomes. BMC Evol. Biol., 8: 96.

19. Kim, A.B., Lee, A.W., Rhee, A.C.K., Kim, B.S.W. and Paick, J.S. (2013) Analysis of DAZ gene expression in a partial AZFc deletion of the human Y chromosome. Rep. Fertil. Dev., 26: 307-315. 
20. Wallis, M.C., Waters, P.D. and Graves, J.A. (2008) Sex determination in mammals - Before and after the evolution of SRY. Cell. Mol. Life Sci., 65: 3182-95.

21. Wilhelm, D., Palmer, S. and Koopman, P. (2007) Sex determination and gonadal development in mammals. Physiol. Rev., 87: 1-28.

22. Turner, M.E., Ely, D., Prokop, J. and Milsted, A. (2011) Sry, more than testis determination. Am. J. Physiol. Regul. Integr. Comp. Physiol., 301: 561-571.

23. Ely, D., Underwood, A., Dunphy, G., Boehme, S., Turner, M. and Milsted, A. (2010) Review of the Y chromosome, Sry and hypertension. Steroids, 75: 747-753.

24. Kido, T. and Lau, Y.F.C. (2015) Roles of the Y chromosome genes in human cancers. Asian J. Androl., 17: 373-380.

25. Looijenga, L.H.J., Hersmus, R., Oosterhuis, J.W., Cools, M. and Drop, S.L.S. (2007) Tumor risk in disorders of sex development (DSD). Best Pract. Res. Clin. Endocrinol. Metab., 21: 480-495.

26. Carneiro, M.C.A., Takeuchi, P.L., Araújo, A., Lôbo, R.B., Elias, F.P., Vila, R.A., Miranda-Furtado, C.L. and Ramos, E.S. (2011) Sexing single bovine blastomeres using TSPY gene amplification. Genet. Mol. Res., 10: 3937-3941.

27. Mukhopadhyay, C.S., Gupta, A.K., Yadav, B.R., Gupta, A., Mohanty, T.K. and Raina, V.S. (2009) HPLC Detection of 8-Hydroxy 2'-Deoxy Guanosine (8-OHdG) in Sperm Nuclear DNA of Subfertile vis-à-vis Healthy bulls, Paper Presented in the "XXVI Annual Conference of Indian Association of Veterinary Pathologists and International Symposium on 'Philosophy of Disease Diagnosis Through Morphological to Biomolecular Approaches' and Core Theme 'Diagnostic Pathology', during October 28-30, 2009. p132

28. Mukhopadhyay, C.S., Gupta, A.K., Yadav, B.R. and Mohanty, T.K. (2011) Exploration of Y-chromosome specific markers to discover SNP associated with sub fertility traits in dairy bulls. Indian J. Biotechnol., 10: 178-182.

29. Sasaki, S. And Shimokawa, H. (1995) The amelogenin gene. Int.J.Dev. Biol. 9: 127-133.

30. Hellborg, L. (2004) Evolutionary Studies of the Mammalian Y-Chromosome. PhD. Thesis Uppsala Universities.

31. Kashyap, V.K., Sahoo, S., Sitalaximi, T. and Trivedi, R. (2006) Deletions in the Y-derived amelogenin gene fragment in the Indian population. BMC Med. Genet., 7: 37.

32. Decarpentrie, F., Vernet, N., Mahadevaiah, S.K., Longepied, G., Streichemberger, E., Aknin-Seifer, I., Ojarikre, O.A., Burgoyne, P.S., Metzler-Guillemain, C. and Mitchell, M.J. (2012) Human and mouse ZFYgenes produce a conserved testis-specific transcript encoding a zinc finger protein with a short acidic domain and modified transactivation potential. Hum. Mol. Genet., 21: 2631-2645.

33. Han, S.H., Yang, B.C., Ko, M.S., Oh, H.S. and Lee, S.S. (2010) Length difference between equine ZFX and ZFY genes and its application for molecular sex determination. J. Assist. Reprod. Genet., 27: 725-728.

34. Laaser, I., Theis, F.J., de Angelis, M.H., Kolb, H.J. and Adamski, J. (2011) Huge splicing frequency in human y chromosomal UTY gene. OMICS A J. Integr. Biol., 15: 141-154.

35. Van der Meulen, J., Sanghvi, V., Mavrakis, K., Durinck, K., Fang, F., Matthijssens, F., Rondou, P., Rosen, M., Pieters, T., Vandenberghe, P., Eric Delabesse, E., Ganapathi, D.M., Karthik, A., Townsley, A.P. and Hsu, D.C. (2015) The H3K27me3 demethylase UTX is a gender-specific tumor suppressor in T-cell acute lymphoblastic leukemia. Blood, 125: 13-21.

36. Li, Y., Wang, M., Piao, F. and Wang, X. (2012)Subchronic exposure to arsenic inhibits spermatogenesis and down regulates the expression of Ddx3y in testis and epididymis of mice. Toxicol. Sci., 128: 482-489.

37. Hamilton, C.K., Revay, T., Domander, R., Favetta, L.A. and King, W.A. (2011) A large expansion of the HSFY gene family in cattle shows dispersion across Yq and testis-specific expression. PLoS One, 15: 76.

38. Komura, K., Jeong, S.H., Hinohara, K., Qu, F., Wang, X., Hiraki, M., Azuma, H., Lee, G.S., Kantoff, P.W. and Sweeney, C.J. (2016) Resistance to docetaxel in prostate cancer is associated with androgen receptor activation and loss of KDM5D expression. Proc. Natl. Acad. Sci. USA., 113(22): 6259-6264

39. Lopes, A.M., Miguel, R.N., Sargent, C.A., Ellis, P.J., Amorim, A. and Affara, N.A. (2010) The human RPS4 paralogue on Yq11.223 encodes a structurally conserved ribosomal protein and is preferentially expressed during spermatogenesis. BMC Mol. Biol., 11: 33.

40. Lahn, B.T. and Page, D.C. (1997) Functional coherence of the human Y-chromosome. Science, 278: 675-680.

41. Yu, X.W., Wei, Z.T., Jiang, Y.T. and Zhang, S.L. (2015) $\mathrm{Y}$ chromosome azoospermia factor region microdeletions and transmission characteristics in azoospermic and severe oligozoospermic patients. Int. J. Clin. Exp. Med., 8(9): 14634-14646.

42. Fischle, W., Robert, A., Franz, H., Jacobs, S.A., Alli, C.D. and Khorasanizadeh, S. (2008) Specificity of the chromodomain $\mathrm{Y}$ chromosome family of chromodomains for lysine-methylated ARK(S/T) Motifs. J. Biol. Chem., 283: 19626-19635.

43. Wang, A.H., Yasue, L., Li, M., Takashima, F.A., de León, P. and Liu, W.S. (2008) Molecular characterization of the bovine chromodomainY-like genes. Anim. Genet., 39: 207-216.

44. Frankenberg, S., Smith, L., Greenfield, A. and ZernickaGoetz, M. (2007) Novel gene expression patterns along the proximo-distal axis of the mouse embryo before gastrulation. BMC Dev. Biol., 7: 8.

45. Mangs, A.H. and Morris, B.J. (2008) ZRANB2: Structural and functional insights into a novel splicing protein. Int. J. Biochem. Cell Biol., 40: 2353-2357.

46. Jarnaess, E., Stokka, A.J., Kvissel, A.N., Skalhegg, B.S., Torgersen, K.M., Scott, J.D., Carlson, C.R. and Taske'n, K. (2009) Splicing factor arginine/serine-rich 17A (SFRS17A) IsanA-kinase anchoring protein that targets protein kinase a to splicing Factor compartments. J. Biol. Chem., 284: 35154-35164.

47. Raudsepp, T. and Chowdhary, B.P. (2015) The eutherian pseudoautosomal region. Cytogenet. Genome Res., 147: 2-3.

48. Birch, J., De Juan Sanjuan, C., Guzman, E. and Ellis, S.A. (2008) Genomic location and characterisation of MIC genes in cattle. J. Immunogenet., 60: 477-483.

49. Ousati Ashtiani, Z., Ayati, M., Modarresi, M.H., Raoofian, R., Sabah Goulian, B., Greene, W.K. and Heidari, M. (2009) Association of TGIFLX/Y mRNA expression with prostate cancer. Med. Oncol., 26(1): 73-77.

50. Hu, Y., Yu, H., Shaw, G., Renfree, M.B. and Pask, A.J. (2011) Differential roles of TGIF family genes in mammalian reproduction. BMC Dev. Biol., 11: 58.

51. Ramadoss, S., Li, J., Ding, X., Hezaimi, K. and Wang, C.Y. (2011) Transducin $\beta$-like protein 1 recruits nuclear factor $\kappa \mathrm{B}$ to the target gene promoter for transcriptional activation. Mol. Cell Biol., 31: 924-934.

52. Taqariello, A., Breuer, C., Birkner, Y., Schmidt, S., Koch, A.M., Cesnjevar, R., Ruffer, A., Dittrich, S., Schneider, H., Winterpacht, A., Sticht, A., Dotsch, J. and Toka, O. (2012) Functional null mutations in the gonosomal homologue gene TBL1Y are associated with non-syndromic coarctation of the aorta. Curr. Mol. Med., 12: 199-205.

53. Cao, P.R., Wang, L., Jiang, Y.C., Yi, Y.S., Qu, F., Liu, T.C. and Lv, Y. (2015) De novo origin of VCY2 from autosome to Y-transposed amplicon. PLoS One, 10: e0119651.

54. Ross, J.L., Tartaglia, N., Merry, D.E., Dalva, M. and Zinn, A.R. (2015) Behavioral phenotypes in males with $X Y Y$ and possible role of increased NLGN4Y expression in autism features. Genes Brain Behav., 14(2): 137-144.

55. Jarvi, K., Lo, K., Fischer, A., Grantmyre, J., Zini, A., 
Chow, V. and Mak, V. (2010) CUA Guideline: The workup of azoospermic males. Can. Urol. Assoc. J., 4: 163-167.

56. Shafina Mohd, N. and Jalaludin, M.Y. (2016) A rare 47 XXY/46 XX mosaicism with clinical features of Klinefelter syndrome. Int. J. Pediatr. Endocrinol., 2016: 11.

57. Sagnak, L., Ersoy, H., Ozok, U., Eraslan, A., Yararbas, K., Goktug, G. and Tukun, A. (2010) The significance of Y chromosome microdeletion analysis in subfertile men with clinical variocele. Arch. Med. Sci., 6(3): 382-387.

58. Yang, F., Silber, S., Leu, N.A., Oates, R.D., Marszalek, J.D., Skaletsky, H., Brown, L.G., Rozen, S., Page, D.C. and Wang, P.J. (2015) TEX11 is mutated in infertile men with azoospermia and regulates genome-wide recombination rates in mouse. EMBO Mol. Med., 7: 1198-1210.

59. O'Brien, K.L., Varghese, A.C. and Agarwal, A. (2010) The genetic causes of male factor infertility: A review. Fertil. Steril., 93: 1-12.

60. Begum, M.R., Khan, A. and Ehsan, M. (2013) Genetic basis of male infertility. Anwer Khan Mod. Med. Coll. J., 4: 37-39.

61. Jo, W.H., Jung, M.K., Kim, K.E., Chae, H.W., Kim, D.H., Kwon, A.R. and Kim, H.S. (2015) XYY syndrome: A 13-year-old boy with tall stature. Ann. Pediatr. Endocrinol. Metab., 20: 170-173.

62. Pradhan, D., Kaman, L., Dhillon, J. and Mohanty, S.K. (2015) Mediastinal mixed germ cell tumor in an infertile male with Klinefelter syndrome: A case report and literature review. J. Cancer Res. Ther., 11: 1034.

63. Morris, J.K., Alberman, E., Scott, C., Patricia, J. (2008) Is the prevalence of Klinefelter syndrome increasing. Eur. J. Hum. Genet. 16(2): 163-170.

64. Chang, S., Skakkebæk, A. and Gravholt, C.H. (2015) Klinefelter syndrome and medical treatment: Hypogonadism and beyond. Hormones, (Athens), 14(4): 531-548.

65. Tyler-Smith, C. and Krausz, C. (2009) The will-o'-the-wisp of genetics-hunting for the azoospermia factor gene. N. Engl. J. Med., 360: 925-927.
66. Stouffs, K., Lissens, W., Tournaye, H. and Haentjens, P. (2010) What about gr/gr deletions and male infertility? Systematic review and meta-analysis. Hum. Reprod. Update, 17: 197-209.

67. Suganya, J., Kujur, S.B., Selvaraj, K.K., Suruli, M.S., Haripriya, G. and Samuel, C.R. (2015) Chromosomal abnormalities in infertile men from southern India. J. Clin. Diagn. Res., 9: GC05-GC10.

68. Poongothai, J., Gopenath, T.S. and Manonayaki, S. (2009) Genetics of human male infertility, (PDF). Singapore Med. J., 50(4): 336-347.

69. Kaur, A., Jamir, J., Bhardwaj, R., Kaur, M., Brah, G.S., Arora, J.S. and Mukhopadhyay, C.S. (2012b) Investigating the role of Holandric Genes (USPY and RBMY) in Sperm Maturity Paper Presented in the International Conference on Sustainable Agriculture for Food and Livestock Security. Poster Presented and Abstract Published in the International Conference on "Sustainable Agriculture for Food and Livestock Security", Organized by Punjab Agricultural University, Ludhiana, Punjab, India, from $27^{\text {th }}$ November to $29^{\text {th }}$ November, 2012. p1405.

70. Choi, J., Koh, E., Suzuki, H., Maeda, Y., Yoshida, A. and Namiki, M. (2007) Alu sequence variants of the BPY2 gene in proven fertile and infertile men with sertoli cell-only phenotype. Int. J. Urol., 14(5): 431-435.

71. Shinka, T., Sato, Y., Chen, G., Naroda, T., Kinoshita, K., Unemi, Y., Tsuji, K., Toida, K., Iwamoto, T. and Nakahori, Y. (2004) Molecular characterization of heat shock - Like factor encoded on the human Y chromosome, and implications for male infertility. Biol. Reprod., 71: 297-306.

72. Kido, T., Schubert, S., Hatakeyama, S., Ohyama, C., Schmidtke, J. and Lau, Y.F.C. (2014) Expression of a Y-located human proto-oncogene TSPY in a transgenic mouse model of prostate cancer. Cell Biosci., 4: 9.

73. Guenther, M.G. (2000) A core SMRT corepressor complex containing HDAC3 and TBL1, a WD40-repeat protein linked to deafness. Genes. Dev., 14: 1048-1057. 